\title{
Collective bargaining and regional wage differences in Spain: An empirical analysis
}

\begin{abstract}
This article analyses the importance of labour market institutions and, in particular, collective wage bargaining in shaping regional wage differences in the Spanish labour market. Using microdata from the Spanish Structure of Earnings Survey, our results reveal that there are significant inter-regional wage differences for similarly skilled workers. These differences are present throughout the whole wage structure and can be explained by both competitive and non-competitive factors, such as an insufficient competition in product markets. In this context, industry-level collective bargaining plays a major role in accounting for regional wage differences, a role that in the Spanish case is enhanced due to its unusual regional dimension.
\end{abstract}

Keywords: Wage structure; Regional wage differences; Collective bargaining.

JEL codes: J31, J50.

Hipólito J. Simón (Corresponding author: hsimon@ua.es)

Instituto de Economía Internacional-Universidad de Alicante

\author{
Raúl Ramos \\ $A Q R$ - Universidad de Barcelona \\ Esteban Sanromá \\ IEB - Universidad de Barcelona
}




\section{Collective bargaining and regional wage differences in Spain: An empirical analysis}

\section{Introduction}

Regional wage differences for similarly skilled workers occur in developed countries with markedly different institutional settings (Teulings and Hartog, 1998). ${ }^{1}$ The magnitude and nature of these wage differentials have, potentially, major implications on the working of the labour market. If regional wage differentials are competitive and wide enough, wages can act as signals for efficient labour allocation between regions. If, on the other hand, certain factors prevent the emergence of regional differences (or generate non-competitive differences), the equalisation of the marginal productivity of similarly skilled workers across the regions is impeded and wages do not adapt properly to differences in local labour market conditions causing a distorting effect in the allocation of labour.

An important issue in this context is the extent to which wage differentials across the regions are conditioned by wage-setting labour market institutions. Statutory minimum wages and, in particular, collective bargaining are major factors in wage determination and, in practice, they have a strong influence on the wage structure of developed countries (Blau and Kahn, 1999 and Nickell and Layard, 1999). Consequently, these factors also have an influence on the magnitude and nature of inter-regional wage differentials. In this sense, the European Union stresses the need to change the systems of collective bargaining and wage determination that, inasmuch as they do not vary from one territory to another in most EU member states, might result in regional wage structures that are inflexible and fail to adjust to 
local labour market conditions (Eurostat, 2003). In this context, the OECD (2004) also highlights the need to analyse "whether certain organisational forms of collective bargaining undermine employment performance by tending to result in (..) a compressed wage structure which does not adequately reflect differences in productivity between workers and regions".

The aim of this article is to analyse inter-regional wage differentials in the Spanish labour market and to establish their relationship with industry-level collective bargaining. We consider the Spanish case to be of great interest within this context for several reasons. First, Spain is one of the few EU countries in which collective agreements at branch level apply just to provinces or regions and in which industrial collective bargaining operates at an infra-national scale (EIRO, 2000). Furthermore, available evidence strongly suggests that the type of industrial collective bargaining influences the magnitude of inter-regional wage differentials (Simón and Russell, 2004), since these differences are much more marked in Spain than in other European countries (namely, Belgium and Italy) where industrial collective bargaining agreements are conducted nationally, or even in those with decentralized systems of collective bargaining where industrial collective bargaining does not occur (Britain). Second, microdata describing industry minimum wages fixed by collective agreements at branch level - i.e. the binding wage scales in the Spanish labour market - are exceptionally available for the Spanish economy. We can therefore examine the real influence of collective bargaining on regional wage differentials. The insights offered by this data constitute a significant novelty as regards existing studies in the literature on wage determination.

Previous studies analysing regional wage differences based on modern theories of 
wage determination are somewhat scarce. Blackaby and Manning (1987) and Blackaby and Murphy (1991) undertook the first studies of this kind, but there has been little continuity, with the sole exception of Mullen and Williams (2001). This article seeks to advance this line of research by exploring the role that collective bargaining plays in shaping inter-regional wage differentials. Although our analysis is limited to this wage-setting institution, we believe that this choice is largely supported by the empirical findings in the literature.

The main contribution of our article to the current literature comprises the use of microdata in directly examining the influence of minimum wages established by industry-level collective bargaining on the determination of regional wages. To the best of our knowledge, empirical evidence on this issue does not exist. This can largely be explained by the scarcity of information on industry minimum wages in European countries where industry-level collective bargaining prevails. ${ }^{2}$

This article is structured as follows. After this introduction, the second section estimates the regional wage differences in the Spanish labour market. The third section examines the degree of similarity in industry minimum wages and actual wages across the Spanish regions. The fourth section identifies those factors that account for inter-regional wage differentials and the extent to which they correspond to competitive explanations of wage determination. The article ends with a summary of the results reported and discusses the main conclusions to be drawn from the analysis.

\section{Inter-regional wage differentials in Spain}

In this section, we estimate Spanish inter-regional wage differentials using cross-section 
microdata drawn from the Structure of Earnings Survey 1995 (Encuesta de Estructura Salarial; hereinafter SES) carried out by the Spanish National Statistics Office (Instituto Nacional de Estadística). The SES is a national sample of salaried workers from randomly selected firms. As the SES comprises a sample of workers at each firm, it consists of matched employer-employee data with a wealth of information on factors concerning the characteristics of the individual, job and workplace. The SES covers Spanish firms employing at least ten workers in economic activities different to agriculture and fisheries and in various service activity branches. After an initial filter of individuals with missing information, those with extremely high and low hourly wages, workers in Ceuta and Melilla, and those with an apprenticeship contract were also filtered out. The final sample comprised 156,009 workers. The wage concept is the natural logarithm of the gross hourly wage. This is calculated as the ratio of gross pay and the number of hours worked per year. Gross pay does not include overtime or bonuses for shift work, night work and/or weekend work.

Our approach to the analysis of inter-regional wage differentials follows the standard procedure in the inter-industry wage literature pioneered by Krueger and Summers (1988) and improved by Haisken-DeNew and Schmidt (1997) ${ }^{3}$. In other words, we estimate a cross-section Mincerian wage equation by restricted least squares of the form:

$$
w_{i j}=\alpha+X_{i} \delta+Z_{j} \beta+E_{j \gamma}+\varepsilon_{i j}
$$

Where $w_{i j}$ denotes the natural logarithm of the gross hourly wage of worker $i$ in region $j$; $X_{i}$ stands for a vector of individual and job controls which are described below; $Z_{j}$ includes a set of mutually exclusive dummies which cover all regions (there are 17 regions in Spain); $E_{j}$ indicates a vector of establishment controls; $\alpha$ is the intercept; $\delta, \beta$ 
and $\gamma$ are vectors of the parameters to be estimated; and $\varepsilon_{i j}$ is a random disturbance term.

The individual controls include a gender indicator and a set of standard human capital variables that comprise an individual's general education (measured as the highest educational qualification achieved), potential experience and its squared value and the time spent with the current employer and its squared value. Potential experience is measured as current age minus age on first entering the labour market after leaving fulltime schooling. Unfortunately, experience has to be approximated because, as is usual in most datasets, we are unable to measure actual experience and this cannot be inferred from the information available in our data. Job controls are dummies for occupational group, a dummy for an indefinite duration contract and a dummy for fulltime job. Workplace controls are industry dummies (the data report industry affiliation at the two-digit NACE nomenclature), firm size dummies and bargaining regime indicators (three types of collective agreements are considered: industry-level collective agreements at a regional level, industry-level collective agreements at the national level and firm-specific agreements).

$\beta$ is the vector of parameters of interest to us in this study. Since the cross-product matrix of regressors of the equation (1) is not one of full rank, the subsequent linear constraint is imposed: $\sum_{j} n_{j} \beta_{j}=0$, where $n_{j}$ is the employment share in region $j$. As in this constrained model every region is assigned a dummy variable (which would produce a singularity in an unconstrained model with a constant term), the restriction on the weighted sum of the region coefficients allows the model to be estimated. Furthermore, it enables us to obtain unbiased standard errors of the coefficients (Haisken-DeNew 
and Schmidt, 1997). The reported region coefficients may be interpreted as (approximately) $^{4}$ the proportionate difference in wages between a worker in a region and the average worker with similar productive and job and workplace characteristics across all regions.

The standard deviation of the regional wage differentials measures their overall variability:

$$
\mathrm{SD}(\beta)=\sqrt{\sum_{j} n_{j} \beta_{j}^{2}-\sum_{j} n_{j} \sigma_{j}^{2}}
$$

Where $\sigma_{j}^{2}$ are the variances of the estimated region coefficients, $\beta_{\mathrm{j}}$, and $\operatorname{SD}(\beta)$ gives the employment-weighted adjusted standard deviation of the $\beta_{\mathrm{j}}^{\prime} \mathrm{s}$. The second term in the equation corrects for the fact that inter-regional wage differences are estimated with an ordinary least squares sampling error that could overestimate the standard deviation of the differentials.

The first column in Table 1 reports inter-regional wage differentials estimated with the full set of controls. ${ }^{5}$ A group significance F-test shows that the null hypothesis that regional wage differentials jointly equal zero can be rejected at better than the $1 \%$ level. Moreover, most of the regional dummy coefficients are statistically significant at conventional significance levels (the exceptions are the non-significant coefficients of Aragon and the Balearic Islands), so that wages in almost every Spanish region typically differ from the national average wage. Regional wage premia range from under $15 \%$ in Extremadura to over $9 \%$ in the Basque Country ${ }^{6}$ and their employmentweighted adjusted standard deviation is of 0.075 log points ${ }^{7}$. Simón and Russell (2004) estimated the magnitude of wage differentials between regions in several developed countries (Italy, Belgium, the United Kingdom and Spain) with harmonised microdata 
from the European Structure of Earnings Survey 1995, and adopting the same methodology applied in this study. ${ }^{8}$ The employment-weighted adjusted standard deviation of the region differentials was of 0.028 log points in Belgium (with three regions being considered); 0.030 in Italy (ten regions); 0.052 in Britain (eleven regions) and 0.067 in Spain (seven regions). This comparative evidence shows that regional wage differentiation is widespread in the Spanish labour market.

\section{(INSERT TABLE 1 ABOUT HERE)}

The first column in Table 2 reports quantile regression estimates of region premia wage differentials at different points in the wage distribution (namely, the 10th, 25th, 50th, 75th and 90th percentiles). ${ }^{9}$ Results indicate that highly significant inter-regional wage differentials exist throughout the wage structure spectrum and that their dispersion is quite similar across different parts of the wage distribution. The same results hold when different occupations are considered. Yet, interestingly, noticeable differences emerge as regards the type of collective agreement. Wage differentials between territories are much more marked for workers covered by branch-level collective agreements at the regional level (the adjusted standard deviation of regional wage differentials is in this case of 0.096$)$ than for those covered by a national branch agreement $(0.053)$ or a firmspecific agreement (0.067). The influence of industry-level collective bargaining at the infra-national level on the shaping of regional wage differentials in the Spanish labour market is, thus, quite compelling.

(INSERT TABLE 2 ABOUT HERE)

An additional issue to note is that the pattern of inter-regional wage differentials is 
largely similar across occupations and in different parts of the distribution, as shown by the high and significant bivariate correlations of those differentials (Tables 3 and 4). This finding confirms that low- and high-wage regions in Spain generally present this feature for all types of worker.

\section{(INSERT TABLES 3 AND 4 ABOUT HERE)}

In order to analyse further the significance of the region in determining wage levels, a wage variance breakdown was carried out. This is based on the estimation of different specifications of the wage equation (1), and it enables us to separate total wage variance into different components, after separately regressing individual wages on a set of regional dummies, on individual and workplace controls and on both sets of attributes. Based on the coefficients of determination of the above wage regressions, this technique allows us to distinguish absolute and marginal fractions of wage variance explained by regions (see the note to Table 5). Regions actually explain a nonnegligible proportion of the variance of individual wages, between 1.8 and $6.8 \%{ }^{10}$ Yet, the relative influence of the region on wage determination varies sharply with the type of collective agreement. In fact, it is much more important for workers covered by industrylevel collective agreements operating regionally (in this case the region accounts for between 3.9 and $10 \%$ of individual wage variability) than for those covered by a national branch $(0.9$ to $4 \%)$ or a firm-specific agreement (1.6 to $4.4 \%)$. This evidence confirms that regional wage variability is strongly related to the structure of industry-level collective bargaining.

(INSERT TABLE 5 ABOUT HERE) 


\section{Industry-level collective bargaining and regional wage differentials}

This section of the article analyzes the influence of industry-level collective bargaining on regional wage determination in the Spanish labour market. In order to put the analysis into context, it begins with a brief description of the Spanish collective bargaining system. Then, after estimating regional differences in minimum wages, this pattern is compared with that of actual wages.

As noted above, collective bargaining and statutory minimum wages are prominent wage-setting institutions. In practice countries with centralised collective bargaining systems and/or with a national minimum wage tend to have more compressed wage structures (Blau and Kahn, 1999 and Nickell and Layard, 1999). The Spanish statutory minimum wage (Salario Mínimo Interprofesional) is among the lowest (relative to the median or average wages) of all developed countries (OECD, 1998). As it is also systematically lower than wage floors set by industry-level collective agreements, it is not actually a binding wage floor. Furthermore, it does not vary between regions. For this reason, this institution is expected to have only a minor influence on the shaping of regional wage differences in the Spanish labour market. As regards the Spanish system of collective bargaining, its main features correspond roughly with those of the centralised systems of other European Union countries (EIRO, 2002). Thus, the most important level of bargaining is branch-level bargaining (although firm-level bargaining also exists); coordination between the different units of negotiation is noticeable (although it is slightly less intense than in other European Union countries: Nickell and Layard, 1999) and the coverage rate is high (85-90\%), largely because collective agreements extend by law to all suitable workers and firms. An unusual feature of the Spanish system, however, is that industry agreements usually operate at an infranational level, and typically take effect at the province level, while, with just a few 
exceptions, in other European countries in which industry-level bargaining is prevalent, industry agreements cover the entire economy (EIRO, 2000).

Industry agreements set wage floors for every occupation (categoría profesional) which, as noted above, constitute the binding minimum wages in the Spanish labour market. These minimum wages differ greatly from one agreement to another within occupations, with particularly large inter-regional differentials (Lorences et al., 1995 and Simón, 2001a). According to available empirical evidence, they also have a strong influence on the actual wage structure of the Spanish labour market (Dolado and Felgueroso, 1997 and Simón, 2001b).

A collective bargaining system in which the effects on wage determination are high and where most of the industry-level collective agreements operate at an infra-national level lends credibility to the argument that inter-regional wage differences in the Spanish labour market might well be influenced by industry minimum wages. This possibility can only be examined thanks to the availability of a database with microdata on industry minimum wages for the Spanish labour market that covers the same industries and the same year, 1995, as the EES. ${ }^{11}$ The analysis is constrained to collective agreements operating at an infra-national level.

Inter-regional differences in industry minimum wages are estimated using a wage equation in which the dependent variable is the agreed wage and the explanatory variables are region dummies and occupation and industry controls: ${ }^{12}$

$$
t_{i j}=\alpha+C_{i} \delta+Z_{j} \beta+S_{j} \gamma+\varepsilon_{i j}
$$

Where $t_{i j}$ denotes the natural logarithm of the minimum wage of occupation $i$ in collective agreement $j ; C_{i}$ stands for a vector of occupation controls; ${ }^{13} Z_{j}$ includes a set 
of mutually exclusive regional dummies which cover all regions; $S_{j}$ indicates a vector of industry controls; $\alpha$ is the intercept; $\delta, \beta$ and $\gamma$ are vectors of the parameters to be estimated; and $\varepsilon_{i j}$ is a random disturbance term.

The empirical results confirm that industry agreements at an infra-national level set minimum wages that differ from one region to another for the same industry and occupation (Table 1). A group significance F-test shows that the null hypothesis that regional wage differentials in agreed wages jointly equal zero can be rejected at better than the $1 \%$ level. Industry minimum wages in almost every Spanish region differ significantly from the national average, with the only exceptions of Murcia and Cantabria. Regionally agreed wage premia range from a low of under $14 \%$ in Extremadura to a high of over $18 \%$ in the Basque Country and the employmentweighted adjusted standard deviation of the region differentials is of 0.080 log points.

Inter-regional differences in actual and agreed wages are roughly similar in dispersion (the adjusted standard deviation is of 0.080 and 0.075 log points) or in pattern (the bivariate correlation coefficient is of 0.8 and statistically significant), which reveals the strong influence of industry-level collective bargaining in shaping regional wage differentials. This influence is particularly marked independent of the type of worker and throughout the whole wage distribution (Table 2). Furthermore, this evidence is consistent with the fact that differences between industry-level collective agreements in industry minimum wages are largely similar for all kinds of worker (Simón, 2001c). The similarity recorded in the inter-regional differences in actual and agreed wages is especially significant for workers covered by industry agreements operating at an infranational level. Yet, the fact that the relationship is also significant for those workers covered by a firm-specific or a national branch agreement requires an explanation. 
Firm-specific agreements improve industry minimum wages through a typical wage drift mechanism, so inter-regional differences in industry minimum wages very plausibly spread to wages set in this level of collective bargaining. On the other hand, to the extent that industry wages in a region are particularly influenced by the wages set in the other industries in the same region (Jimeno and Bentolila, 1998 and Bajo et al., 1999), spillover effects in regional wage determination from those industries covered by regional collective bargaining to those covered by national collective agreements may well account for this latter effect.

Annual changes in industry minimum wages are very similar in all the regions of Spain (Alonso and Izquierdo, 1999). As a result, inter-regional differences in industry minimum wages can be expected to be roughly the same from one year to the next, which is consistent with the time persistence of inter-regional differences in actual wages (Villaverde and Maza, 2002) and, finally, with a non-transitory influence of collective bargaining in shaping regional wage differences.

In short, the overall empirical evidence clearly suggests that inter-regional wage differences in the Spanish labour market are driven by industry-level collective bargaining. It is, therefore, important for us to determine whether these wage differentials correspond to a competitive wage determination mechanism. This matter is examined in section 4 below.

\section{The nature of the regional wage structure}

Regional wage differences can be related to the existence of a competitive labour market, in which wages act as signals for the efficient reallocation of labour by 
migration. Alternatively, wage differences can also be related to non-competitive factors that impede the equalisation of the labour marginal productivities of similar workers living in different regions. In this second case, wages would distort the efficient allocation of labour and this could have adverse effects via unemployment and income inequality (OECD, 2000).

Competitive explanations of permanent inter-regional wage differences are based on labour supply characteristics - human capital, regional price characteristics, compensatory differences (Rosen, 1986), or differences in the amenities of the different regions that equalise the utility of workers between them (Blackaby and Murphy, 1991 and OECD, 2000). The other regional wage differences that do not affect workers' utility should disappear through labour and capital mobility (Blackaby and Manning, 1987).

The inter-regional wage differences for Spain estimated in the previous section are for workers with similar human capital levels and their geographical structure does not seem to be transitory. For this reason, wage differences would only be competitive in nature if they were related to differences in price levels or other non-monetary factors. In order to test this possibility, we re-estimated the wage equation (1) substituting the regional dummies with the price level for each region and with other regional variables related to non-monetary factors. Thus, equation (1) is replaced with the following model:

$$
w_{i j}=\alpha+X_{i} \delta+R_{j} \beta+E_{j} \gamma+\varepsilon_{i j}
$$

Where $R_{j}$ represents the different variables related to the aforementioned characteristics of region $j$.

However, the theoretical results reported by Moulton (1986) show that in models 
such as (4) the use of OLS would cause an upward bias in the values of the t-statistic for the explanatory variables defined at a higher level of aggregation than that of the endogenous variable. For this reason, equation (4) is estimated using Feasible Generalized Least Squares (FGLS) following Rauch (1993). The estimation process is specifically focused so as to obtain a consistent estimation of the variancecovariance matrix of the error term (taking into account its regional structure) as well as to use this matrix to transform the original data properly and obtain efficient estimates for the coefficients considered.

The logarithm of the regional price level presented the expected positive sign for each of the specifications, in line with the competitive approach (Table 6). Regional price differences thus influence wage differences, so that workers seek to obtain compensation to cover the differences in regional costs of living. This result holds when regional housing prices are included in the specification.

\section{(INSERT TABLE 6 ABOUT HERE)}

Inter-regional wage differences also compensate for the unequal attraction of Spanish regions as certain regional characteristics related to the attractiveness of the territories are statistically significant and present the signs predicted by compensatory differences theory (columns II to $\mathrm{V}$ of Table 6). In particular, the advantages associated with a coastal location or with a better climate compensate for lower wage incomes. Similarly, leisure attractions and health facilities have the same compensatory effect. Thus, a part of the Spanish regional wage differences is caused by competitive factors. 
Regional productivity differences related to unequal efficiency levels or to the limited mobility of some factors might generate wage differences that cannot be attributed to competitive mechanisms. As the main determinant of productivity is the accumulation of capital (physical, human and technological), we included some of these factors in the specification. As individual human capital is already controlled in equation (4), we only considered the influence of the regional private physical stock and the regional technological level ( $R+D$ expenses). The separate inclusion of these two factors provided similar results: both have a positive and significant effect on productivity and regional wages. $^{14}$

The possibility that firms might obtain monopoly rents due to the insufficient competition of market products should make it possible for them to pay higher wages (Groshen, 1991). Therefore, if the competitive pressure varies between the regions, the rents generated and the wages paid might also differ. The results obtained when including an indicator of competition in regional product markets in the analysis clearly confirm this effect, as even a simple indicator (the ratio between imports and GDP) is significant with the expected negative sign.

But imperfections are not limited to market products. In fact, the labour market is characterized by a set of regulations and institutional factors that condition the functioning of market forces. During the last few decades, theoretical research on wage determination mechanisms have highlighted the role of the workers' bargaining power, in particular, that of insiders, given the impact of unemployment on the strategy and behaviour of the agents. ${ }^{15}$ According to these models, strong union bargaining power and a low unemployment rate will lead to higher wages. The inclusion in the regression of proxy variables to reflect both effects confirms this impact: union power (measured as 
the success of strikes) has a positive and significant effect on regional wages, while the unemployment rate has a negative effect, regardless of the inclusion of other regional characteristics (columns IV and V of Table 6).

A negative effect of the unemployment rate on wages is the opposite to what one would expect in a competitive framework of wage bargaining, as wages should be higher to compensate workers in regions with higher unemployment rates (Harris and Todaro, 1970). However, a negative relationship best fits the predictions of the aforementioned non-competitive theories. The value of the elasticity of wages to the regional unemployment rates is -0.03 , which is clearly below that of -0.10 that seems to be an empirical regularity in developed countries (Blanchflower and Oswald, 1994), and also below the estimates for Spain provided by García and Montuenga (2003) and by Sanromá and Ramos (2003). This low value could be the effect of certain level of territorial aggregation (here NUTS II).

Summarising, the results obtained, and in particular those related to the effect of limited competition on market products and institutional factors on the labour markets, provide direct evidence of the non-competitive nature of regional wage differences. These results suggest that regional wage differences in Spain do not encourage, at least in part, an efficient allocation of labour resources. It should also be considered that labour mobility is very low in Spain, as inter-regional migrations have responded only very weakly in the past to wage differentials and employment opportunities as measured by regional unemployment rates (Jimeno and Bentolila, 1998), so that a distinctive feature of the Spanish labour market are regional unemployment disparities that tend to persist (Sáez and Murillo, 1996). 
In order to confirm the influence of collective bargaining on regional wage differences, we conducted a final empirical analysis. This analysis consisted of analysing whether the variables accounting for regional wage differences also explain regional differences in industry minimum wages. If these variables explain regional industry minimum wages, the importance of collective bargaining in determining explaining regional wage differences would be confirmed. In order to do this, we replaced equation (3) with the following model:

$$
t_{i j}=\alpha+C_{i} \delta+R_{j} \beta+S_{j} \gamma+\varepsilon^{\prime \prime}{ }_{i j}
$$

Where $R_{j}$ represents the different variables related to the aforementioned characteristics of region $j$.

The results of estimating this equation were as expected (Table 7). With the sole exceptions of housing prices and leisure attractions, which were no longer statistically significant, the explanatory factors of actual wages also accounted for industry minimum wages fixed by rounds of collective bargaining.

\section{(INSERT TABLE 7 ABOUT HERE)}

The results also highlight a number of additional points. First, one difference between Tables 6 and 7 is that the physical capital stock has been replaced by R+D expenses. In fact, the physical capital stock does not explain adequately the industry minimum wage, while $R+D$ expenses are clearly statistically significant. As both variables might reflect the effects of productivity differences on wages, this substitution does not seem to be particularly relevant ${ }^{16}$. A second aspect that is worth mentioning is the fact that the compensatory variables have the expected signs (with the previously mentioned exceptions) and are statistically significant at the usual levels. From this it can be 
deduced that in the bargaining process, social agents bear the characteristics of the territory very much in mind, so it cannot be claimed that unions distort the bargaining process without mentioning that they also give some prominence to certain supply or competitive factors.

A third issue to be emphasised is that the values of the coefficients are, in general, higher for the models in which the endogenous variable is the industry minimum wage (Table 7) than in those in which the analysed variable are actual wages (Table 6). Furthermore, these differences are statistically significant. The elasticity to prices is higher for industry minimum wages, which can be interpreted as evidence of an indexation of agreements higher than for actual wages. The elasticity of industry minimum wages to external competition is also higher, which implies that the framework for the distribution of firms' rents is collective bargaining. Finally, the variables related to labour market conditions are also more significant for industry minimum wage than they are for actual wages. Thus, non-competitive wage determination theories show a greater explanatory capacity for bargained wages than for actual wages. This result seems reasonable as actual wages are also influenced by individual characteristics that have only been partially controlled by individual explanatory variables in the wage equation, and which are translated into a wage drift that is totally alien to labour market institutions.

It can be concluded that the same factors - both competitive and non-competitive - that account for the industry minimum wage also account for actual wages. For this reason, the non-competitive nature of inter-regional wage differences is already present in regional collective agreements. In this sense, the role of collective bargaining in determining inter-regional wage differences is clearly strengthened. 


\section{Conclusions}

The Spanish economy is characterised by the presence of marked wage differences between workers with the same level of skills. These differences are related to regional allocation patterns. In practice, inter-regional wage differences are an important factor in determining individual wages and are present at all levels of the wage structure, with the implication that relative regional wages are very similar for all workers.

The existence of inter-regional wage differences for similarly skilled workers challenges the possibility that these differences might be explained by different human capital levels across the regions. Inter-regional wage differences cannot be fully explained by other competitive factors and, as a result, these differences do not contribute to a more efficient functioning of the wage setting mechanism and a more efficient Spanish labour market. In this line of reasoning, our results show that limited and unequal competition levels in product markets and certain restrictions operating on factor accumulation induce regional wage differences that hinder an efficient factor allocation at the regional level.

The main contribution of this article is the empirical demonstration that inter-regional wage differences are related to the characteristics of the collective bargaining system. The evidence reported here reveals that collective bargaining is responsible for the existence of such wage differences. Inter-regional differences in actual and bargained wages are extremely similar, which indicates that the regional structure of bargained wages at the sectoral level is largely the origin of regional wage differences in the Spanish labour market. Moreover, the influence of the territory in determining wage 
levels is more important for workers covered by regional sectoral agreements than for workers covered by national agreements. This shows that the influence of collective bargaining in generating regional wage differences is enhanced by the regional dimension of the system in the Spanish case, where sectoral agreements for territories at a level below that of the national level predominate. From a comparative perspective, inter-regional wage differences in the Spanish labour market are very high. In this sense, our evidence suggests that the presence of sectoral agreements at the national level - a common feature in more than one European Union country - limits wage flexibility and leads to a lower regional wage differentiation.

Finally, the same competitive and non-competitive factors that account for the bargained industry minimum wage also determine actual wages, which strengthens the significance of the collective bargaining system in the generation of inter-regional wage differences. 


\section{References}

Alcaide, J.; Alcaide, C. (1999): "Homogeneización de las series regionales 1986-1997", Papeles de Economía Española, vol. 80, pp. 292-314.

Alonso, J.; Izquierdo, M. (1999): "Disparidades regionales en el empleo y el desempleo", Papeles de Economía Española, vol. 80, pp. 79-98.

Bajo, O.; Rabadán, I.; Salas, R. (1999): “Regional Wage Flexibility in Spain, 1989-1992”, Regional Science Review, vol 18, pp. 63-73.

Blackaby, D.H.; Manning, D.N. (1987): "Regional Earnings Revisited”, The Manchester School, vol. LV, 2, pp. 158-183.

Blackaby, D.H.; Murphy, P.D. (1991): "Industry Characteristics and Inter-regional Wage Differences", Scottish Journal of Political Economy, vol. 38(2), pp. 142-61.

Blanchflower, D.G.; Oswald, A.J. (1994): “Estimating a Wage Curve for Britain 1973-1990”, Economic Journal, vol. 104 (426), pp. 1025-1043.

Blau, F.D.; Kahn, L.M. (1999): "Institutions and Laws in the Labor Market", in O. Ashenfelter and D. Card (ed.) Handbook of Labor Economics, ed. North-Holland, vol. 3, cap. 25.

Boyer, R.; D. Savageau (1985): Places Rated Almanac, Rand McNally, Chicago.

Buchinsky, M. (1994): “Changes in the US structure 1963-1987: Application of quantile regression", Econometrica, vol. 62, pp. 405-458.

Cardoso, A.R.; Portugal, P. (2003): "Bargaining Wages, Wage Drift and the Design of the Wage Setting System", IZA Discussion Paper VOL. 914.

Dolado, J.J.; Felgueroso, F. (1997): "Los efectos del salario mínimo: evidencia empírica para el caso español", Moneda y Crédito, vol. 204, pp. 213-254.

Dolado, J.J., Felgueroso, F.; Jimeno, J.F. (1997): "The effects of minimum bargained wages on earnings: Evidence from Spain”, European Economic Review, vol. 41, pp. 713-721.

European Industrial Relations Observatory (2000): "Wage policy and EMU", available at http://www.eiro.eurofound.eu.int

European Industrial Relations Observatory (2002): "Industrial relations in the EU Member States and candidate countries", available at http://www.eiro.eurofound.eu.int

Eurostat (2002): Employment in Europe 2002.

Eurostat (2003): Employment in Europe 2003. 
Farber, H. (1986): "The Analysis of Union Behavior" in O. Ashenfelter and R. Layard (eds.) Handbook of Labor Economics, Elsevier Science Publishers, vol. 2, chap. 18.

Fundación BBVA (2002): Stock de capital en España y su distribución territorial (1964-2000).

García, I.; Montuenga, V. (2003): “The Spanish Wage Curve: 1994-1996”, Regional Studies, vol. 37, 9, pp. 929-945.

Groshen, E.L. (1991): "Five Reasons why Wages Vary among Employers”, Industrial Relations, vol. 30, pp. 350-381.

Haisken-DeNew, J.P.; Schmidt, C. (1997): "Interindustry and Interregion Differentials: Mechanics and Interpretation", Review of Economics and Statistics, 79, pp. 516-521.

Harris, J.R.; Todaro, M.P. (1970): "Migration, Unemployment and Development: A Two-Sector Analysis", American Economic Review, vol. 60 (1), pp. 126-142.

Hirschberg, Joe; Lye, Jenny (2001): “The Interpretation of Multiple Dummy Variable Coefficients: An Application to Industry Effects in Wage Equations", Applied Economics Letters, vol. 8 (11), pp. 701-707.

Jimeno, J. F.; Bentolila, S. (1998): "Regional Unemployment Persistence (Spain, 1976-1994)”, Labour Economics, vol. 5, pp. 25-51.

Koenker, R.; Bassett, G. (1978): “Regression Quantiles”, Econometrica, vol. 46, pp. 33-50.

Krueger, A.B.; Summers, L. (1988): "Efficiency Wages and the Inter-industry Wage Structure", Econometrica, vol. 56(2), pp. 259-93.

Lindbeck, A.; Snower, D. (1988): The Insider-Outsider Theory of Employment and Unemployment, MIT Press, Cambridge, Massachusetts.

Lorences, J.; Fernández, V.; Rodríguez, C. (1995): “Diferencias interterritoriales de salarios y negociación colectiva en España", Investigaciones Económicas, vol. XIX(2), pp. 309-324.

Moulton, B.R. (1986): "Random Group Effects and the Precision of Regression Estimates", Journal of Econometrics, vol. 32, pp. 385-397.

Mullen, J.K.; Williams, M. (2001): "Regional Efficiency Wages: Are they a Source of Real Earnings Differentials?", Review of Urban and Regional Development Studies, vol. 13, 3, pp. 244-260.

Nickell, S.; Layard, R. (1999): 'Labor market institutions and economic performance', in O. Ashenfelter and D. Card (eds.) Handbook of Labor Economics, ed. North-Holland.

OECD (1998): "Making the Most of the Minimum: Statutory Minimum Wages, Employment and Poverty" Employment Outlook, Chapter 2 (available at www.oecd.org). 
OECD (2000): "Disparities in regional labour markets", Employment Outlook, Chapter 2 (available at www.oecd.org).

OECD (2004): Employment Outlook 2004 (available at www.oecd.org).

Rauch, J. (1993): “Productivity Gains from Geographic Concentration of Human Capital: Evidence from the Cities", Journal of Urban Economics, vol. 34, pp. 380-400.

Rosen, S. (1986): "The Theory of Equalizing Differences," in Ashenfelter, O.C. and R. Layard (eds.), Handbook of Labor Economics, North-Holland, Vol. I, chap. 12.

Sáez, M.; Murillo, C. (1996): "Regional Disparities and National Similarities in Spanish Unemployment: A Case of Seasonal Cointegration?", Applied Economics, vol. 28 (12), pp. 1529-44.

Sanromá, E.; Ramos, R. (2003): "Wage Curves for Spain. Evidence from the Family Budget Survey", Documento de Trabajo de la Facultat de Ciències Econòmiques i Empresarials de la UB $\mathrm{n}$. E03/101.

Shapiro, C.; Stiglitz, J. (1984): "Equilibrium Unemployment as a worker discipline device", American Economic Review, vol. 74, pp. 433-444.

Simón, H. (2001a): “La estructura de salarios pactados en España”, Estudios de Economía Aplicada, vol. 19 (3), pp. 48-67.

Simón, H. (2001b): "Negociación colectiva y determinación salarial en España”, Hacienda Pública Española, vol. 157-2 pp. 325-346.

Simón, H. (2001c): "Negociación colectiva sectorial y tarifas salariales", Revista del Ministerio de Trabajo y Asuntos Sociales serie Economía y Sociología, vol. 31, pp. 55-70.

Simón; H.; Russell, H. (2004): “Firms and the Gender Wage Gap: A Cross-National Comparison”, Center for Economic Performance Pay Inequalities and Economic Performance Discussion Paper.

Teulings, C.; Hartog, J. (1998): Corporatism or competition? Labour contracts, institutions and wage structures in international comparison, ed. Cambridge University Press.

Villaverde, J.; Maza, A. (2002): "Salarios y desempleo en las regiones españolas", Papeles de Economía Española, vol. 93, pp. 182-194. 
Table 1

Inter-regional wage differences in the Spanish labour market. 1995.

\begin{tabular}{|c|c|c|c|c|}
\hline \multirow[t]{2}{*}{ Region } & \multicolumn{2}{|c|}{$\begin{array}{c}\text { Actual wages (Structure } \\
\text { of Earnings Survey) }\end{array}$} & \multicolumn{2}{|c|}{$\begin{array}{c}\text { Industry minimum wages } \\
\text { (NUTS II and NUTS III } \\
\text { industry-level collective } \\
\text { agreements) }\end{array}$} \\
\hline & Coefficient & $\begin{array}{l}\text { Standard } \\
\text { error }\end{array}$ & Coefficient & $\begin{array}{l}\text { Standard } \\
\text { error }\end{array}$ \\
\hline Andalusia & $-0.008^{* *}$ & 0.003 & $-0.011^{*}$ & 0.004 \\
\hline Aragon & -0.004 & 0.004 & $-0.049 * *$ & 0.008 \\
\hline Asturias & $-0.030 * *$ & 0.004 & 0.024 * & 0.011 \\
\hline Balearic Islands & -0.003 & 0.005 & $0.080 * *$ & 0.022 \\
\hline Canary Islands & $-0.084^{* *}$ & 0.004 & $-0.034 * *$ & 0.009 \\
\hline Cantabria & $-0.024 * *$ & 0.004 & -0.022 & 0.007 \\
\hline Castilla-La Mancha & $-0.062 * *$ & 0.004 & -0.076 ** & 0.005 \\
\hline Castilla y León & $-0.041^{* *}$ & 0.003 & $-0.059 * *$ & 0.012 \\
\hline Catalonia & $0.078^{* *}$ & 0.002 & $0.055^{* *}$ & 0.005 \\
\hline Comunidad Valenciana & $-0.022 * *$ & 0.003 & $-0.025 * *$ & 0.006 \\
\hline Extremadura & $-0.148 * *$ & 0.006 & $-0.143 * *$ & 0.012 \\
\hline Galicia & $-0.142 * *$ & 0.003 & $-0.102 * *$ & 0.006 \\
\hline Madrid & $0.079 * *$ & 0.002 & 0.016 * & 0.008 \\
\hline Murcia & $-0.122^{* *}$ & 0.004 & -0.039 ** & 0.011 \\
\hline Navarra & $0.080 * *$ & 0.004 & $0.113^{* *}$ & 0.012 \\
\hline Basque Country & $0.090 * *$ & 0.003 & 0.177 ** & 0.007 \\
\hline Rioja & $-0.016^{* *}$ & 0.006 & 0.056 ** & 0.015 \\
\hline $\begin{array}{c}\text { Adjusted standard deviation } \\
\text { Observations }\end{array}$ & \multicolumn{2}{|c|}{$\begin{array}{c}0.075 \\
156,009\end{array}$} & \multicolumn{2}{|c|}{$\begin{array}{l}0.080 \\
5,632\end{array}$} \\
\hline
\end{tabular}

Note: Regional dummy coefficients measure differences relative to the national average wage and were estimated using restricted least squares in equations (1) and (2). ${ }^{* *}$ and ${ }^{*}$ indicate that the variable is statistically significant at the $1 \%$ and $5 \%$ levels, respectively.

Table 2

Adjusted standard deviation of inter-regional wage differences and correspondence between the regional differences in actual and bargained wages 1995.

\begin{tabular}{|c|c|c|}
\hline & $\begin{array}{c}\text { Adjusted standard } \\
\text { deviation }\end{array}$ & $\begin{array}{c}\text { Correspondence } \\
\text { between regional } \\
\text { differences in } \\
\text { bargained and actual } \\
\text { wages }\end{array}$ \\
\hline ALL WORKERS & $0.075^{* *}$ & $0.822^{* *}$ \\
\hline PERCENTILE & & \\
\hline Percentile 10 & $0.076^{* *}$ & $0.834^{* *}$ \\
\hline Quartile 25 & $0.074^{\star *}$ & $0.871^{* *}$ \\
\hline Median & $0.076^{* *}$ & $0.848^{* *}$ \\
\hline Quartile 75 & $0.079^{* *}$ & $0.779^{* *}$ \\
\hline Percentile 90 & $0.081^{* *}$ & $0.677^{* *}$ \\
\hline OCCUPATION & & \\
\hline Labourers & $0.083^{* *}$ & $0.748^{* *}$ \\
\hline Manual qualified workers & $0.080^{* *}$ & $0.861^{* *}$ \\
\hline Administrative workers & $0.060^{* *}$ & $0.729^{* *}$ \\
\hline Technicians & $0.075^{\star *}$ & $0.703^{\star *}$ \\
\hline Medium and highly qualified workers & $0.064^{* *}$ & $0.599 * *$ \\
\hline Managers & $0.100^{* *}$ & $0.665^{\star *}$ \\
\hline Type of Collective AgREEMENT & & \\
\hline National & $0.053^{* *}$ & $0.727^{* *}$ \\
\hline Regional & $0.096^{* *}$ & $0.843^{\star *}$ \\
\hline Firm-specific & $0.067^{* *}$ & $0.748^{* *}$ \\
\hline
\end{tabular}

Note: The values in the left-hand column are the adjusted standard deviations of the coefficients of the regional dummy variables estimated from wage equation (1). As indicated in the table, these differentials were estimated for the whole sample but also for different groups of workers, and in different percentiles of the distribution of individual wages. ${ }^{* *}$ indicates that wage differences are statistically different from zero with a significance level lower than $1 \%$. The right-hand column shows the value of Pearson's bivariate correlation coefficient of the regional dummy coefficients estimated in wage equations (1) and (2). ${ }^{* *}$ and ${ }^{*}$ indicate that the correlation is statistically significant at the $1 \%$ and $5 \%$ levels, respectively, in a bilateral test. 
Table 3

Correspondence of inter-regional wage differences by occupational groups. Structure of Earnings Survey 1995.

\begin{tabular}{|c|c|c|c|c|c|c|}
\hline & 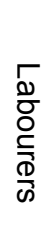 & 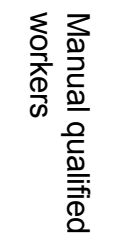 & 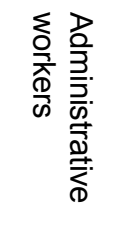 & 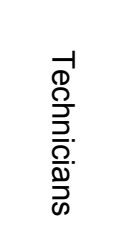 & 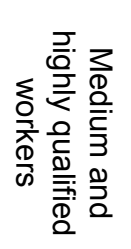 & 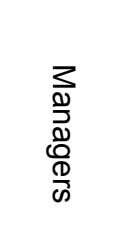 \\
\hline Labourers & 1 & $0.925^{\star *}$ & $0.910^{* *}$ & $0.724^{* *}$ & $0.865^{\star *}$ & $0.739^{* *}$ \\
\hline Manual qualified workers & & 1 & $0.883^{\star *}$ & $0.769^{* *}$ & $0.752^{* *}$ & $0.720^{* *}$ \\
\hline Administrative workers & & & 1 & $0.846^{* *}$ & $0.855^{\star *}$ & $0.749^{* *}$ \\
\hline Technicians & & & & 1 & $0.746^{* *}$ & $0.846^{* *}$ \\
\hline Medium and highly qualified workers & & & & & 1 & $0.796^{* *}$ \\
\hline Managers & & & & & & 1 \\
\hline
\end{tabular}

Note: The values of Pearson's bivariate correlation coefficient for each pair of coefficients of the regional dummy variables in the different estimations of wage equation (1) for each occupational group. ${ }^{* *}$ and * indicate that the correlation is statistically significant at the $1 \%$ and $5 \%$, respectively, in a bilateral test.

\section{Table 4}

Correspondence of inter-regional wage differences in the different percentiles of the wage structure. Structure of Earnings Survey 1995.

\begin{tabular}{|c|c|c|c|c|c|}
\hline & 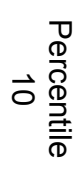 & 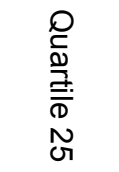 & $\begin{array}{l}\frac{3}{\mathbb{1}} \\
\frac{0}{0}\end{array}$ & 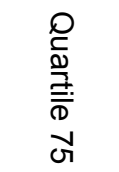 & 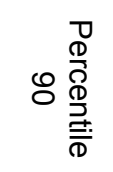 \\
\hline Percentile 10 & 1 & $0.976^{\star *}$ & $0.901^{* *}$ & $0.787^{* *}$ & $0.675^{\star}$ \\
\hline Quartile 25 & & 1 & $0.969 * *$ & $0.892^{* *}$ & $0.800^{* *}$ \\
\hline Median & & & 1 & $0.974^{* *}$ & $0.912^{* *}$ \\
\hline Quartile 75 & & & & 1 & $0.975^{\star *}$ \\
\hline Percentile 90 & & & & & 1 \\
\hline
\end{tabular}

Note: The values of Pearson's bivariate correlation coefficient for each point of the wage distribution of the coefficients of the regional dummy variables in the different estimations of wage equation (1) for each percentile. ${ }^{* *}$ and * indicate that the correlation is statistically significant at the $1 \%$ and $5 \%$, respectively, in a bilateral test.

\section{Table 5}

Regional and individual wage variability in the Spanish labour market. Structure of Earnings Survey 1995.

\begin{tabular}{|l|c|c|}
\hline \multirow{2}{*}{} & \multicolumn{2}{|c|}{$\begin{array}{c}\text { Variability of individual wages explained } \\
\text { by the region (\%) }\end{array}$} \\
\cline { 2 - 3 } & $\begin{array}{c}\text { Minimum bound } \\
\left(R_{A}^{2}-R_{B}^{2}\right) \times 100\end{array}$ & $\begin{array}{c}\text { Maximum bound } \\
\left(R_{C}^{2}\right) \times 100\end{array}$ \\
\hline ALL WORKERS & 1.8 & 6.8 \\
TYPE OF COLLECTIVE BARGAINING AGREEMENT & & 4.0 \\
National & 0.9 & 10.0 \\
Regional & 3.9 & 4.4 \\
Firm-specific & 1.6 & \\
\hline
\end{tabular}

Note: $R_{C}^{2}, R_{B}^{2}$ and $R_{A}^{2}$ are the values of the goodness of fit coefficient in three different specifications of the wage equation including, respectively, the following explanatory variables: regional dummies, only the rest of explanatory variables in equation (1), and both sets of variables. 
Table 6

Regional wages and regional characteristics.

\begin{tabular}{|l|ccccc|}
\hline & $I$ & $I I$ & $I I I$ & $I V$ & $V$ \\
\hline Price level (log) & $0.8154^{* *}$ & $1.3313^{* *}$ & $1.2655^{* *}$ & $1.3817^{* *}$ & $1.2889^{* *}$ \\
Housing price level(log) & $0.1174^{* *}$ & $0.0789^{* *}$ & $0.0671^{* *}$ & $0.0743^{* *}$ & $0.0610^{* *}$ \\
Amenities & & & & & \\
$\quad$ Coast kilometres (log) & - & $-0.0001^{* *}$ & $-0.0001^{* *}$ & $-0.0001^{* *}$ & $-0.0123^{* *}$ \\
$\quad$ Climatic mildness indicator & - & $-0.0001^{*}$ & $-0.002^{* *}$ & 0.0001 & $-0.0002^{* *}$ \\
$\quad$ Number of cinemas per capita (log) & - & $-0.0707^{* *}$ & $-0.0562^{* *}$ & $-0.0753^{* *}$ & $-0.0614^{* *}$ \\
$\quad$ Hospital beds per capita (log) & - & $-0.0614^{* *}$ & $-0.0403^{* *}$ & $-0.0756^{* *}$ & $-0.0571^{* *}$ \\
Physical capital stock (log) & - & - & $0.0120^{* *}$ & - & $0.0156^{* *}$ \\
External competition indicator & - & - & $-0.0081^{* *}$ & - & $-0.0087^{* *}$ \\
Non-agriculture unemployment rate (log) & & - & - & $-0.0158^{* *}$ & $-0.0312^{* *}$ \\
Trade unions bargaining power indicator & - & - & - & $0.0099^{* *}$ & $0.0107^{* *}$ \\
\hline
\end{tabular}

Note: Estimated coefficients for the variables indicated in the left-hand column when they are included in wage equation (3) replacing the regional dummy variables. ${ }^{* *}$ and * indicate that the coefficient is statistically significant at the $1 \%$ and $5 \%$ level, respectively. These estimates were obtained using Feasible Generalized Least Squares as proposed by Rauch (1993). The regional price level for 1995 was calculated from the estimates of relative regional price levels by FIES (Alcaide and Alcaide, 1999). The regional housing price level was defined as the average price per square meter in 1995 for new housing according to the web page of the Ministerio de Fomento. Coast kilometres, the number of cinemas per capita and hospital beds per capita were obtained from the Anuario Estadístico de España by the Instituto Nacional de Estadística. The climatic mildness indicator was obtained by applying the methodology proposed in the Places Rated Almanac by Boyer and Savageau (1985) using information from the Anuario Estadístico de España. The private physical capital stock data for 1995 (excluding agriculture and fishery) in each region was obtained from Stock de Capital en España y su distribución territorial (1964-2000) of Fundación BBVA. The external competition indicator was defined as the ratio between the imports in each region and its Gross Domestic Product in 1995 according to the Contabilidad Regional de España for 1995, prepared by the Instituto Nacional de Estadística. Regional non-agriculture unemployment rates were calculated as the average of the quarterly data for 1995 in the Encuesta de Población Activa, prepared by the Instituto Nacional de Estadística. Finally, the trade unions bargaining power indicator measures the capability of trade unions to go on strike. In particular, it is defined as the ratio of workers on strike in each region in the case of general strikes during the period 1992-1995 (Boletín de Estadísticas Laborales).

Table 7

Regional industry minimum wage and regional characteristics

\begin{tabular}{|l|ccccc|}
\hline & $I$ & $I I$ & $I I I$ & $I V$ & $V$ \\
\hline Price level (log) & $1.4304^{* *}$ & $1.5646^{* *}$ & $1.6425^{* *}$ & $1.5575^{* *}$ & $1.6382^{* *}$ \\
Housing price level(log) & $0.0454^{* *}$ & $0.0544^{* *}$ & $0.0489^{* *}$ & 0.0098 & 0.0090 \\
Attraction factors & & & & & \\
$\quad$ Coast kilometres (log) & - & $-0.0001^{* *}$ & $-0.0001^{* *}$ & $-0.0001^{* *}$ & $-0.0001^{* *}$ \\
$\quad$ Climatic mildness indicator & - & $-0.0007^{*}$ & $-0.0005^{* *}$ & $-0.0007^{* *}$ & $-0.0008^{* *}$ \\
$\quad$ Number of cinemas per capita (log) & - & $-0.0332^{* *}$ & $-0.0140^{* *}$ & $0.0294^{* *}$ & 0.0268 \\
$\quad$ Hospital beds per capita (log) & - & $-0.1330^{* *}$ & $-0.0863^{* *}$ & $-0.1074^{* *}$ & $-0.0761^{* *}$ \\
R+D expenses related to GDP & - & - & $0.0280^{* *}$ & - & $0.0322^{* *}$ \\
External competition indicator & - & - & $-0.0566^{* *}$ & - & $-0.0363^{* *}$ \\
Non-agriculture unemployment rate (log) & & - & - & $-0.0972^{* *}$ & $-0.0698^{* *}$ \\
Trade unions bargaining power indicator & - & - & - & $0.0381^{* *}$ & $0.0297^{* *}$ \\
\hline
\end{tabular}

Note: Estimated coefficients for the variables indicated in the left-hand column where they are included in the wage equation (4) replacing the regional dummy variables. ${ }^{* *}$ and * indicate that the coefficient is statistically significant at the $1 \%$ and $5 \%$ level, respectively. These estimates have been obtained using Feasible Generalized Least Squares as proposed by Rauch (1993). Regional data of R+D expenses related to GDP were obtained from Estadisticas sobre actividades de $1+D$ and Contabilidad Regional de España, both prepared by the Instituto Nacional de Estadística. For the definition and sources of the rest of variables, see the Note to Table 6. 


\section{Endnotes}

${ }^{1}$ A more general analysis of territorial disparities in labour markets can be found in OECD (2000) and Eurostat (2002).

${ }^{2}$ There are, however, some important exceptions. Dolado et al. (1997) and Lorences et al. (1995) examine the characteristics of industry minimum wages and their influence on wage determination in Spain using limited samples of branch collective agreements. In turn, Cardoso and Portugal (2003) infer industry minimum wages for the Portuguese economy from the distribution of actual wages and analyse their determinants.

${ }^{3}$ An application of this procedure can be found in Hirschberg and Lye (2001).

${ }^{4}$ Percentage difference is calculated as $\left(\mathrm{e}^{\beta j}-1\right)^{*} 100$, where $\beta_{j}$ is the relevant coefficient.

5 The estimated wage equation appears to be meaningful as the returns on the personal and workplace characteristics are consistent with those in the literature on wage determination. Full results are not reported, but are available from the authors on request.

${ }^{6}$ This implies that actual wages in Basque Country are about 28\% higher than in Extremadura for all skill levels.

${ }^{7}$ If regional dummies are further interacted with individual controls the adjusted standard deviation of regional coefficients remains fairly similar. Assuming in the specification of the Mincerian wage equation that relative wage differences over skills are the same for each region is not, thus, a strong assumption.

${ }^{8}$ The SES is the Spanish national sample of the European Structure of Earnings Survey 1995, a grouping of national surveys conducted by the statistical offices of the European Union countries according to a standard methodology designed by Eurostat.

${ }^{9}$ Quantile regression techniques allow the impact of a variable on particular points of the conditional distribution of wages to be estimated, given the other explanatory variables in the model. This contrasts with OLS, which estimates the conditional mean of wages given the explanatory variables. For a discussion of quantile regressions, see Koenker and Bassett (1978) and Buchinsky (1994).

10 Note that the territorial influence on wage determination may be underestimated. Regional information in the SES refers to the Spanish regions, whilst a wider territorial variability is highly plausible at the province level (the 17 Spanish regions divide into 50 provinces), to the extent that this finer territorial reference is the usual reference in non-national collective agreements in Spain. 
${ }^{11}$ More details on the database can be found in Simón (2001c).

${ }^{12}$ As in Section 2, the equation is estimated by restricted least squares, with the constraint that the employment-weighted sum of the regional dummy coefficients equals zero. As long as the information available on the number of workers covered by each industry agreement is not reliable, the employment weights used are those derived from the Labour Force Survey (Encuesta de Población Activa).

${ }^{13}$ Seven occupations are considered: university degree, non-university degree, skilled white collar semi-skilled white collar, skilled blue collar, semi-skilled blue collar, and unskilled blue collar.

${ }^{14}$ The high bivariate correlation between both variables $(0.57)$ and between these and other variables related to regional productivity (firm size, foreign capital presence) suggest that they should not be included in the model at the same time due to problems of collinearity. For this reason, we only included capital stock.

${ }^{15}$ Farber (1986) and Blau and Khan (1999) provide a summary of the literature on the role of trade unions in wage determination. The role of unemployment rates on wage levels has been considered in insider-outsider models (Lindbeck and Snower, 1988) and, particularly, in some versions of wage efficiency models (Shapiro and Stiglitz, 1984).

${ }^{16}$ A possible explanation for this result might be that territories (firms) in which activities of $R+D$ are significant can guarantee higher wages, which are included in the collective bargaining agreements. However, in the other regions (firms), the strategy might be to negotiate wage complements linked to productivity, which could increase - if there are no innovations - by introducing physical capital. This argument would explain why the industry minimum wage might be related to $R+D$ expenses but not to the physical capital stock. It should be pointed out that as there is no empirical evidence supporting the argument, this explanation is purely tentative. 